\title{
Kemampuan Pemecahan Masalah Materi Listrik Dinamis pada Pembelajaran Guided Inquiry Berbantuan PhET pada Mahasiswa S1 Pendidikan Fisika
}

\author{
Cicyn Riantoni, Lia Yuliati, dan Nandang Mufti \\ Pascasarjana Pendidikan Fisika Universitas Negeri Malang \\ Jalan Semarang 5 Malang \\ Surat-e: cicynriantoniI2@gmail.com
}

\begin{abstract}
Tujuan Penelitian ini adalah untuk mengetahui kemampuan pemecahan masalah mahasiswa setelah dibelajarkan dengan pembelajaran guided inquiry berbantuan $\mathrm{PhET}$. Penelitian ini menggunakan pendekatan mixed method dengan desain embeded eksperimental model. Subjek penelitian terdiri dari 35 mahasiswa pendidikan fisika Universitas Negeri Jambi yang sedang menempuh mata kuliah Fisika Dasar II. Hasil penelitian menunjukkan bahwa terjadi peningkatan skor kemampuan pemecahan masalah mahasiswa setelah dibelajarkan dengan pembelajaran guided inquiry berbantuan PhET dengan $N$-gain dalam kategori sedang dan effect size dalam kategori kuat. Jika dilihat dari daya beda pretest dan posttest didapatkan nilai $t$ sebesar 12,48 dengan signifikansi 0,000. Hasil ini menunjukkan kemampuan pemecahan masalah sebelum diajarkan dan setelah diajarkan guided inquiry berbantuan PhET berbeda secara signifikan dengan nilai posttest lebih baik dari pretest.
\end{abstract}

The aim of this study is to know the ability of student's problem solving after studied with guided inquiry and PhET simulations. This study used mixed method with a design of the embedded experimental model to get result of research. The subjects are 35 students of physics education in Jambi University who learning basic physics. The result shows that scores of students problem-solving ability increase after learned with guided inquiry assisted $\mathrm{PhET}$ with $\mathrm{N}$-Gain in the medium category and the effect size in the high category. If viewed from different pretest and posttest show $t$ values 12,48 and 0,000 significance. These results indicate that skill of problem-solving before and after learned with collaborate guided inquiry and $\mathrm{PhET}$ significantly different with the value of posttest is better than the pretest.

Kata kunci: pemecahan masalah, guided inquiry, PhET, listrik dinamis

\section{Pendahuluan}

Konsep dasar listrik dinamis seperti hukum Ohm, arus, tegangan dan hambatan dalam rangkaian seri dan paralel serta energi dan daya listrik merupakan konsep penting yang harus dikuasai mahasiswa dalam bidang kelistrikan. Beberapa penelitian menunjukkan banyak mahasiswa yang masih sulit dalam memahami masalah konsep listrik dinamis $[\mathrm{I}, 2,3]$. Mahasiswa tidak mengalami kesulitan menggunakan hukum Ohm untuk menyelesaikan masalah yang sederhana, akan tetapi mahasiswa banyak salah ketika menggunakan hukum Ohm untuk menganalisis rangkaian yang lebih komplek [I]. Banyak mahasiswa yang salah dalam mengambarkan dan menginterpretasikan diagram rangkaian $[2,3]$. Selain itu juga mahasiswa salah dalam memahami konsep arus listrik yang mengangap arus akan berkurang dalam suatu rangkaian [3].

Salah satu faktor yang mempengaruhi masih sulitnya mahasiswa dalam menyelesaikan permasalahan listrik dinamis adalah masih lemahnya kemampuan mahasiswa dalam menerapkan konsep dalam proses pemecahan masalah. Padahal pemecahan masalah merupakan keterampilan penting dan merupakan hal utama dalam pendidikan sains [4] serta merupakan faktor kunci dalam pembelajaran fisika [16]. Selain itu juga mahasiswa yang diajarkan memecahkan masalah hanya berfokus pada persamaan sebagai pusat untuk memperoleh jawaban dan cenderung mengabaikan informasi konseptual juga merupakan faktor yang mempengaruhi masih lemahnya kemampuan pemecahan masalah mahasiswa [5]. 
Pembelajaran guided inquiry merupakan salah satu solusi yang dapat diterapkan untuk meningkatkan kemampuan pemecahan masalah mahasiswa, khususnya dalam menerapkan konsep dalam proses pemecahan masalah. Hal ini dikarenakan guided inquiry bersifat student center [6]. Pembelajaran guided inquiry membantu mahasiswa untuk mengembangkan tangung jawab individu, kognitif, membuat laporan, memecahkan masalah dan keterampilan [7]. Selain itu juga penerapan pembelajaran guided inquiry dapat mengembangkan pemahaman pada mahasiswa tidak hanya produk tetapi juga proses [8].

Pembelajaran guided inquiry dapat dikoloborasi dengan media virtual seperti Physics Education Technology $(\mathrm{PhET})$. Penggunaan laboratorium virtual dapat mendukung dalam mengembangkan pemahaman konseptual $[9, \mathrm{IO}, \mathrm{I}$ I , I2] dan membantu mahasiswa untuk memahami fenomena fisik dalam berbagai lingkup pembelajaran fisika [IO]. Penggunaan media PhET sebagai simulasi juga dapat membantu mahasiswa dalam memahami fenomena sehari-hari dengan konsep yang mendasarinya, misalnya model-model fisik seperti arus listrik dan medan magnet [I3] yang tidak dapat ditunjukkan dalam laboratorium fisik.

Tujuan penelitian ini adalah untuk mengetahui kemampuan pemecahan masalah mahasiswa pada materi listrik dinamis setelah dibelajarkan dengan pembelajaran guided inquiry berbantuan $\mathrm{PhET}$ interactive simulations.

\section{Kajian Pustaka}

\section{Pemecahan Masalah}

Sejalan dengan penguasaan konsep, pemecahan masalah merupakan salah satu faktor kunci dalam pendidikan fisika [16]. Proses pemecahan masalah biasanya digunakan oleh pengajar fisika sebagai mekanisme untuk mengajarkan materi fisika dan untuk menilai jika suatu materi sudah dipelajari $[\mathrm{I} 2, \mathrm{I}]$.

Ada beberapa kerangka pemecahan masalah yang diterapkan dalam pembelajaran fisika. Kerangka minnesota membagi 5 kriteria pemecahan masalah, yaitu focus the problem, describe the physics, plan and solutions, execute the plan and evaluate the answer [4]. Sedangkan Docktor dan Mestre membagi kerangka pemecahan masalah menjadi lima kriteria, yaitu usefull description, physics approach, specific aplication of physics, mathematical procedure and logical progression [I6].

Penilaian skill pemecahan masalah mahasiswa dalam penelitian ini berdasarkan kriteria kerangka pemecahan masalah yang dikembangkan Docktor dan Mestre [16]. Hal ini dikarenakan fokus peneliti dalam penelitian ini adalah bagaimana mahasiswa bisa menerapkan konsep dalam proses pemecahan masalah dan tidak hanya terpaku pada rumus atau variabel. Penilaian usefull description dilakukan berdasarkan bagaimana mahasiswa mengorganisasikan pernyataan masalah dan menggunakan informasi dalam pemecahan masalah. Penilaian physics approach dilakukan berdasarkan penggunaan dan ketepatan konsep fisika yang diterapkan dalam pemecahan masalah. Penilaian specific application of physics dilakukan berdasarkan proses dalam mengaplikasikan konsep fisika yang melibakan kuantitas dan variabel dalam proses. Penilaian mathematical procedures dilakukan berdasarkan bagaimana mahasiswa menggunakan prosedur matematika dalam memecahkan masalah. Sedangkan logical progression dinilai berdasarkan proses solusi masalah secara keseluruhan yang terkait dengan kejelasan, fokus dan terorganisir secara logis.

Dalam proses pemecahan masalah fisika, ada banyak pendekatan yang cenderung digunakan mahasiswa. Lima jenis pendekatan pemecahan masalah yang biasa digunakan mahasiswa antara lain scientific approach, structured munner plug-and-chug, unstructured munner plug-and-chug, memory based approach dan no clear approach [19]. Akan tetapi jika dilihat dari bagaimana pendekatan expert dan novice dalam memecahkan masalah, ada beberapa karakteritik yang membedakannya. Antara lain adalah expert memecahkan masalah cenderung memulai dengan mendeskripsikan masalah secara kualitatif [19,23], sedangkan novice cenderung memecahkan masalah memulai dengan langsung memanipulasi rumus [23]. Expert memecahkan masalah berdasarkan konsep [22], sedangkan novice tidak menggunakan konseptual dalam proses pemecahan masalah [23]. Expert mengorganisasikan pengetahuan secara terstruktur, sedangkan novice tidak memerlukan pengetahuan terstruktur, pemahaman mereka dilakukan secara acak dan persamaan yang digunakan tidak berdasarkan pengetahuan konseptual [19].

\section{Guided Inquiry}

Inquiry merupakan jalan yang digunakan oleh saintis untuk mempelajari alam dan menyampaikannya berdasarkan hasil temuan [24]. Ada empat jenis inquiry yang biasa diterapkan dalam pembelajaran, diantaranya adalah confirmation inquiry, structured inquiry, guided inquiry dan open or full inquiry [25]. Dalam pembelajaran inquiry dapat melatih mahasiswa dalam penyelidikan ilmiah, sehingga mereka memahami bagaimana seorang ilmuan melakukan penemuan [30].

Guided inquiry merupakan jenis inquiry level ketiga yang dalam pembelajarannya siswa diberikan pertanyaan, tetapi prosedur dan jawaban pertanyaan tersebut tidak disediakan karena fokus dari pembelajaran ini adalah mahasiswa menentukan sendiri prosedur percobaan untuk menjawab pertanyaan yang diberikan oleh guru [25]. Hal 
ini dilakukan karena responden akan menerima konsep secara penuh jika mereka menemukan jawaban mereka sendiri, daripada diberitahukan jawaban [28].

Langkah inquiry yang diterapkan dalam penelitian ini mengadaptasi dari langkah inquiry yang dikembangkan pada Tabel I [26]. Banyak keuntungan penggunaan guided inquiry dalam pembelajaran, diataranya pembelajaran guided inquiry membawa mahasiswa membangun pengetahuan berdasarkan bermacam-macam konsep fisika [27]. Penarapan inquiry tidak hanya dapat membawa mahasiswa mengingat fakta ilmiah dan informasi, melainkan tentang menerapkan konsep dan metode ilmiah [26].

Tabel I Sintak Pembelajaran Guided Inquiry [26]

\begin{tabular}{|c|c|}
\hline Indikator & Aktivitas pembelajaran \\
\hline $\begin{array}{l}\text { Orienting And } \\
\text { Asking } \\
\text { Questions }\end{array}$ & $\begin{array}{l}\text { Siswa melakukan pengamatan atau } \\
\text { mengamati fenomena imiah untuk meningkat } \\
\text { minat mereka atau membangkitkan rasa ingin } \\
\text { tahu mereka. }\end{array}$ \\
\hline $\begin{array}{l}\text { Hipotesis } \\
\text { Generation }\end{array}$ & $\begin{array}{l}\text { Siswa mengembangkan hipotesis untuk } \\
\text { menjawab masalah yang diberikan guru. Pada } \\
\text { tahap ini biasanya siswa mengembangkan } \\
\text { hipotesis berdasarkan informasi dan } \\
\text { pengalaman dalam kehidupan sehari-hari }\end{array}$ \\
\hline Planning & $\begin{array}{l}\text { Planning dalam arti sempit melibatkan } \\
\text { pengembangan prosedur eksperimen untuk } \\
\text { menguji hipotesis. Dalam guided inquiry siswa } \\
\text { diberi kebebasan untuk membuat prosedur } \\
\text { eksperimen untuk menguji hipotesi dan } \\
\text { menemukan konsep }\end{array}$ \\
\hline Investigations & $\begin{array}{l}\text { Investigasi merupakan aspek empiris dari } \\
\text { pembelajaran inquiry. Ini menyangkut } \\
\text { penggunaan alat-alat untuk mengumpulkan } \\
\text { informasi, implementasi eksperimen dan } \\
\text { pengorganisasian data }\end{array}$ \\
\hline $\begin{array}{l}\text { Analysis and } \\
\text { Interpretations }\end{array}$ & $\begin{array}{l}\text { Mengumpulkan data, mengorganisasikan, dan } \\
\text { mengnalisis akurasi dan presisi data. Sealin itu } \\
\text { juga pada tahap ini siswa. Siswa } \\
\text { menginterpretasikan data dalam berbagai } \\
\text { bentuk seperti grafik }\end{array}$ \\
\hline $\begin{array}{l}\text { Model } \\
\text { Ekploration } \\
\text { and creation }\end{array}$ & $\begin{array}{l}\text { Model digunakan memiliki beberapa tujuan. } \\
\text { Siswa menggunakan model untuk } \\
\text { mengeksplorasi, menguji, merevisi dan untuk } \\
\text { penguatan hasil investigasi. Hal ini dapat } \\
\text { dilakukan dengan menggunakan bantuan } \\
\text { teknologi dan matematis untuk menguji hasil } \\
\text { investigasi }\end{array}$ \\
\hline $\begin{array}{c}\text { Conclusion and } \\
\text { Evaluation }\end{array}$ & $\begin{array}{l}\text { Dalam kegiatan menarik kesimpulan dan } \\
\text { evaluasi, siswa mengambil hasil dari } \\
\text { penyelidikan. Kesimpulan mungkin diambil } \\
\text { dari data dan dibandingkan dengan model, } \\
\text { teori atau percobaan lain. }\end{array}$ \\
\hline Communication & $\begin{array}{l}\text { Pada tahap ini siswa melaporkan hasil dari } \\
\text { investigasi dan konsep apa yang mereka } \\
\text { temukan, selain itu juga siswa belajar } \\
\text { bagaimana menyampaikan alasan kesimpulan } \\
\text { yang ambil }\end{array}$ \\
\hline Prediksi & $\begin{array}{l}\text { Pada tahap ini siswa mungkin menemukan } \\
\text { pertanyaan-pertanyaan baru dan bersamaan } \\
\text { dengan guru menjelaskan mengungkapkan } \\
\text { masalah tersebut }\end{array}$ \\
\hline
\end{tabular}

\section{PhET Interactive Simulations}

PhET merupakan salah satu bentuk laboratorium virtual yang dikembangkan oleh Universitas Colorado yang difokuskan untuk pembelajaran fisika $[9,13,31]$, namun demikian PhET juga menyediakan beberapa simulasi untuk pembelajaran kimia [9,3I], biologi, matematika dan sains lainnya [3I]. Simulasi ini dapat digunakan dalam banyak setingan yang menyangkut dosen, individu atau aktivitas inquiry dalam grup kecil, tugas rumah dan laboratorium [9]. Selain itu juga dalam pembelajaran fisika PhET dibagi dalam beberapa sub materi, seperti gerak; usaha, energi dan daya; kalor dan termodinamika; listrik dan rangkaian; cahaya dan radiasi; fenomena kuantum; kimia; alat matematika [3I].

Dalam pembelajaran, PhET dirancang untuk membangun hubungan antara pemahaman sehari-hari mahasiswa dan prinsip fisika yang mendasarinya serta menjelaskan fenomena yang tidak bisa diamati secara langsung dengan laboratorium real seperti atom, elektron, foton, medan listrik $[9,13,3 I]$. Selain itu juga bantuan PhET dalam pembelajaran dapat meningkatkan akses mahasiswa untuk memahami konsep dan merepresentasikannya [I3], memberikan kesempatan kepada mahasiswa untuk berinteraksi dengan visual dinamis, membuat mahasiswa fokus dalam eksplorasi inquiry, memberikan feed back yang cepat dan memiliki banyak representasi [32].

\section{Metode Penelitian}

Penelitian ini menggunakan pendekatan mixed method dengan desain embedded eksperimental model untuk menggali secara lengkap subjek penelitian. Pada penelitian mixed method terdapat dua jenis metode penelitian yang diterapkan, yaitu metode penelitian kuantitatif dan kualitatif. Metode penelitian kuantitatif digunakan untuk memperoleh data tentang kemampuan pemecahan masalah mahasiswa, sedangan metode penelitan kualitatif digunakan untuk mengetahui lebih mendalam jawaban mahasiswa dan alasan jawaban mahasiswa yang tidak jelas.

Subjek penelitian adalah mahasiswa $S_{\text {I }}$ Pendidikan Fisika Universitas Negeri Jambi yang sedang menempuh mata kuliah fisika dasar yang terdiri dari satu kelas. Jumlah responden sebanyak 35 mahasiswa.

Data dalam penelitian ini diperoleh melalui tes dan wawancara. Soal yang digunakan peneliti adalah soal pilihan ganda beralasan yang dikembangkan dengan merujuk pada soal DIRECT (Determining and Interpreting Resistive Electric Circuit Concept) [I4]. Soal yang digunakan terdiri dari 7 butir soal yang telah melalui validasi ahli dan uji empiris dengan rata-rata validitas soal sebesar 0,53 dan reliabilitas 0,78 dengan kriteria reliabilitas tinggi. Hasil dari tes digunakan peneliti sebagai 
panduan untuk melakukan wawancara dengan tujuan memperjelas jawaban mahasiswa.

Pengumpulan data dilakukan melalui pretest dan posttest. Pretest dilakukan untuk mengumpulkan data awal penelitian berdasarkan tes kemampuan pemecahan masalah mahasiswa serta wawancara. Data yang diperoleh berupa data kuantitatif dari skor jawaban mahasiswa dan data kualitatif dari jawaban wawancara. Selama proses pembelajaran, peneliti melakukan pengamatan terhadap aktivitas mahasiswa dalam berdiskusi dan bereksperimen. Pengamatan dilakukan dengan bantuan lembar observasi untuk melihat keterlaksanaan pembelajaran. Setelah proses pembelajaran berakhir dilakukan posttest untuk memperoleh data perkembangan kemampuan pemecahan masalah mahasiswa.

Dalam melakukan penilaian kemampuan pemecahan masalah mahasiswa peneliti menggunakan rubrik penilaian pemecahan masalah yang terdiri dari 5 kriteria penilaian, yaitu usefull description, aplication of physics, spesific aplications of physics, mathematical prosedure dan logical progeression [I5].

\section{Hasil Penelitian dan Pembahasan}

Salah satu pembelajaran yang dapat dapat diterapkan untuk meningkatkan kemampuan pemecahan masalah mahasiswa pada materi listrik dinamis adalah pembelajaran guided inquiry berbantuan PhET. Dalam penelitian ini pembelajaran guided inquiry berbantuan PhET yang diterapkan merupakan salah satu bentuk pembelajaran kolaborasi, karena dalam proses pembelajarannya menggabungkan antara percobaan menggunakan laboratorium real dan percobaan menggunakan laboratorium virtual. Penggunaan bantuan laboratorium virtual atau simulasi bertujuan untuk pemantapan konsep yang akan diterapkan dalam pemecahan masalah. Penggunaan virtual bersamaan dengan metodologi pemecahan masalah dalam pembelajaran dapat berkontribusi dalam meningkatkan kemampuan pemecahan masalah mahasiswa [I2]. Selain itu juga, penggunaan media komputer dan pendekatan konseptual merupakan salah satu strategi untuk membantu mahasiswa menjadi lebih baik dalam pemecahan masalah [16].

Peningkatan kemampuan pemecahan masalah mahasiswa pada materi listrik dinamis setelah dibelajarkan dengan pembelajaran guided inquiry berbantuan PhET dapat dilihat dari perubahan skor pretest dan posttest yang merupakan hasil tes dan wawancara. Hasil rata-rata pretest dan posttest dapat dilihat pada Gambar I. Dari skor rata-rata terlihat bahwa terjadi peningkatan skor kemampuan pemecahan masalah mahasiswa setelah dibelajarkan dengan pembelajaran guided inquiry berbantuan PhET dari skor rata-rata pretest 7,59 menjadi
5 I,03 pada posttest. Data tersebut didukung dengan hasil uji daya beda, $N$-gain dan effect size pada Tabel 2 .

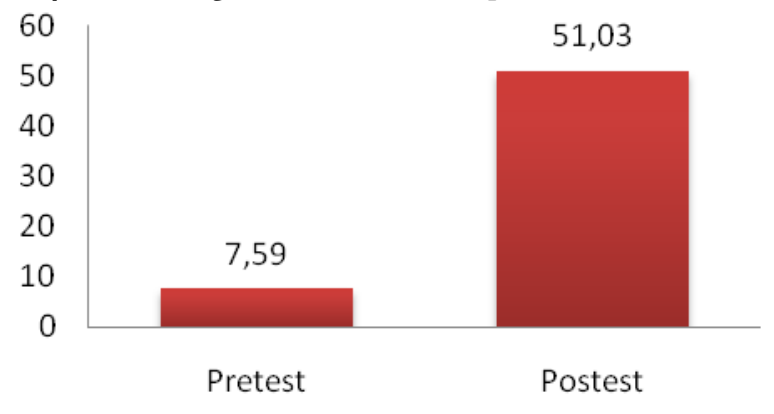

Gambar I. Perubahan Nilai Rata-rata Kemampuan Pemecahan Masalah Mahasiswa

Tabel 2. Hasil Uji Beda, N-Gain dan Effect size Pretest dan Posttest.

\begin{tabular}{lll}
\hline Statistik & Nilai & Kategori \\
\hline Nilai $t$ & $\mathrm{I} 2,48$ & \\
Asymp. Sig. (2-tailed) & 0,000 & Perbedaan signifikan, \\
(Paired Sample Test) & & Posttest > Pretest \\
N-Gain & 0,5 & sedang \\
Cohen's d-effect size & 2,7 & Efek kuat \\
\hline \hline
\end{tabular}

Data pada Tabel 2 menunjukkan bahwa terjadi peningkatan yang signifikan kemampuan pemecahan masalah mahasiswa setelah dibelajarkan dengan pembelajaran guided inquiry berbantuan PhET. Skor hasil uji paired $t$ test menunjukkan nilai $t$ sebesar I2,48 dengan tingkat signifikansi 0,000 lebih kecil dari 0,05. Dari hasil tersebut dapat disimpulkan kemampuan pemecahan masalah mahasiswa sebelum diajarkan dan setelah diajarkan dengan pembelajaran guided inquiry berbantuan PhET berbeda secara signifikan. Dalam hal ini kemampuan pemecahan masalah mahasiswa setelah diajarkan pembelajaran guided inquiry berbantuan $\mathrm{PhET}$ lebih tinggi dibandingkan sebelum diajarkan.

Jika dilihat dari kekuatan operasional pembelajaran terhadap peningkatan kemampuan pemecahan masalah mahasiswa termasuk dalam kategori kuat dengan nilai effect size sebesar 2,7. Hasil ini membuktikan bahwa pembelajaran kolaborasi guided inquiry berbantuan PhET dapat digunakan untuk meningkatkan kemampuan pemecahan masalah mahasiswa pada materi listrik dinamis. Hasil ini sesuai dengan penelitian sebelumnya bahwa mahasiswa yang dibelajarkan dengan pembelajaran koloborasi inquiry yang memanfaatkan dukungan media komputer akan memberikan pengaruh secara langsung terhadap pengetahuan mahasiswa, pemahaman konsep dan keterampilan pemecahan masalah [I7]. Selain itu juga, bantuan media komputer seperti laboratorium virtual dapat meningkatkan akses mahasiswa dalam menghasilkan konsep dan merepresentasikanya [I3]. Dukungan kolaborasi eksperimen real dan virtual memberikan kualitas hasil pengetahuan yang lebih baik daripada menggunakan ekperimen real saja atau eksperimen dengan virtual saja [I I]. 
Dua buah bola lampu yang identik yaitu lampu A dan B dirangkai dengan sebuah baterai seperti pada Gambar 1. Jika anda menambahkan hambatan C dengan besar yang sama dengan hambatan dalam bola lampu A dan B dalam rangkain tersebut seperti pada Gambar 2, maka perubahan yang terjadi pada terangnya lampu A dan B jika dibandingkan sebelum ditambahkan resistor $\mathrm{C}$ adalah....
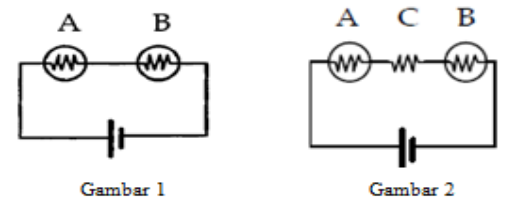

a. A tetap Sama, B meredup

eredup, B tetap sam

c. A dan B lebih teran

A dan B meredup

Gambar

A dan B tetap sama

Gambar 2. Soal Kemampuan Pemecahan Masalah

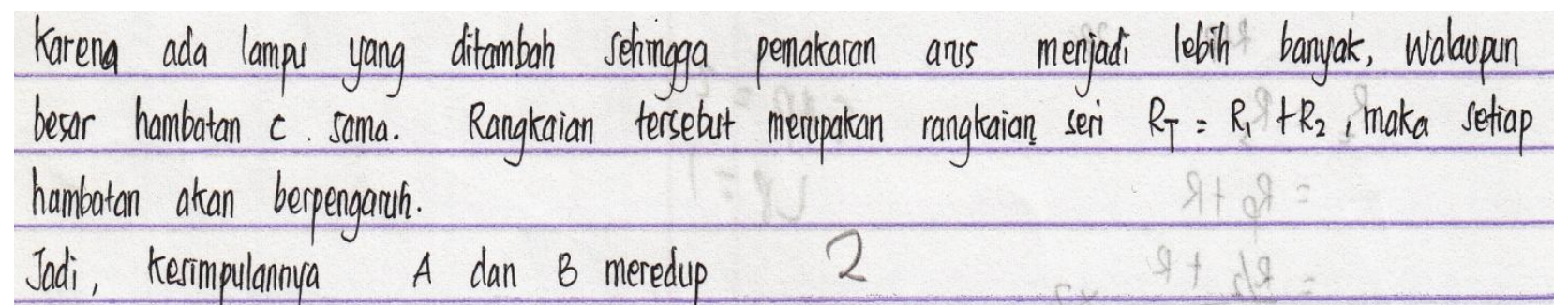

(a)

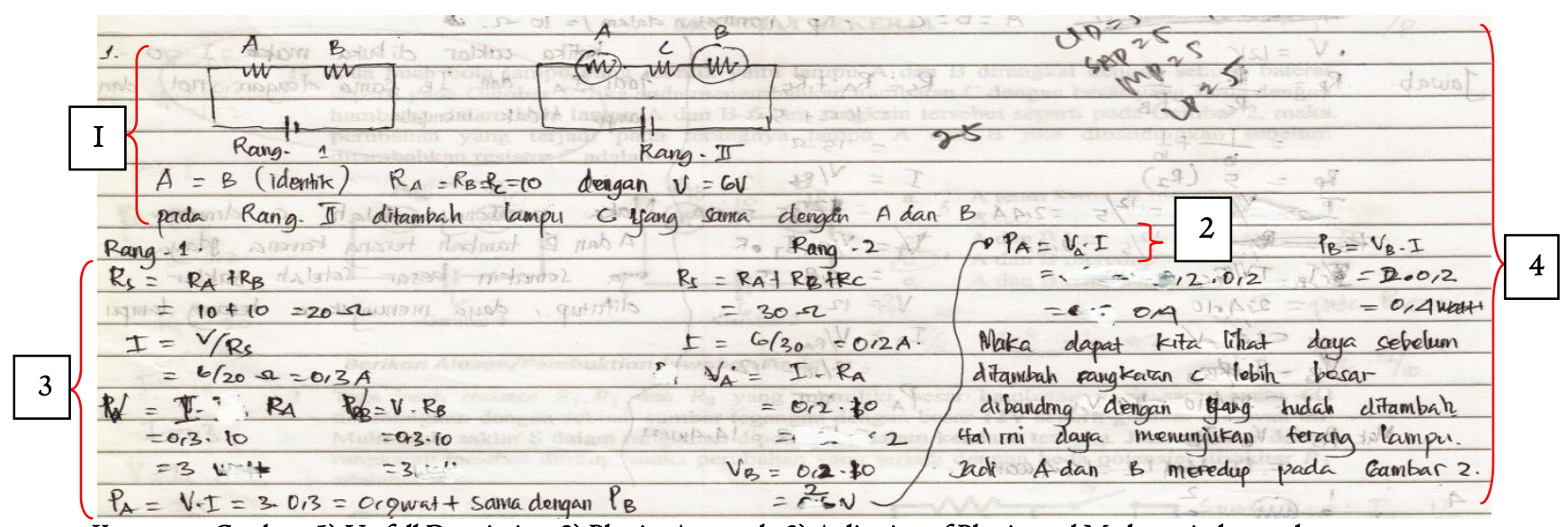

Keterangan Gambar : I) Usefull Description, 2) Physics Approach, 3) Aplication of Physics and Mathematical procedure,

4) Logical Progression

Gambar 3. Contoh Hasil Pemecahan Masalah Mahasiswa Sebelum (a) dan Sesudah Intervensi (b)

Contoh peningkatan kemampuan pemecahan masalah mahasiswa dapat dilihat dari bagaimana salah satu mahasiswa memecahkan masalah Gambar 2 pada saat pretest dan posttest. Dalam hal ini mahasiswa diberikan masalah untuk mengaplikasikan konsep hubungan arus, tegangan dan hambatan dalam suatu rangkaian sehingga dapat menentukan perubahan terangnya dua buah bola apabila ditambahkan suatu hambatan dalam rangkain tersebut.

Gambar 3 menunjukkan perbedaan proses pemecahan masalah salah satu mahasiswa (mahasiswa nomor I4) sebelum dan sesudah dibelajarkan dengan pembelajaran guided inquiry berbantuan PhET. Pada saat pretest pada Gambar 3a terlihat bahwa mahasiswa memecahkan masalah berdasarkan logika tanpa adanya proses penerapan konsep dan matematis dalam mendapatkan jawaban. Hal ini disebabkan oleh mahasiswa belum memahami konsep untuk diterapkan dalam proses pemecahan masalah, padahal membantu mahasiswa dengan pemahaman konseptual dan matematis sangat mendukung proses pemecahan masalah [33].

Gambar 3b merupakan hasil jawaban posttest bentuk proses pemecahan masalah mahasiswa setelah dibelajarkan dengan guided inquiry berbantuan PhET. Hasil pada Gambar $3 \mathrm{~b}$ memperlihatkan peningkatan kemampuan pemecahan masalah mahasiswa yang telah sesuai dengan kriteria penilaian proses pemecahan masalah yang terdiri dari usefull description, physics approach, aplication of physics, mathematical procedure and logical progression [15]. Pada jawaban posttest Gambar 3b terlihat mahasiswa mengawali proses memecahkan masalah dengan mendeskripsikan masalah dalam bentuk gambar dan peminsalan matematis. Walaupun dalam soal tidak diterangkan variabel yang diketahui, tetapi peminsalan 
matematis yang digunakan oleh mahasiswa memberikan kemudahan dalam proses mendapatkan jawaban. Hal ini menunjukkan mahasiswa sudah mampu menerapkan usefull desciption dengan sangat baik. Selanjutnya mahasiswa menerapkan konsep dengan benar seperti beberapa rumus yang menunjukkan bagian dari physics approach dan aplication of physics. Dalam proses pemecahan masalah mahasiswa juga terlihat menggunakan proses matematis yang benar yang merupakan bagian dari mathematical procedure. Diakhir proses pemecahan masalah terlihat bahwa mahasiswa membuat suatu kesimpulan dari temuan yang ditemukan, selain itu juga proses pemecahan masalah mahasiswa terlihat sangat sistematis yang merupakan bagian dari logical progression. Proses pemecahan masalah yang dilakukan mahasiswa pada saat posttest menunjukkan peningkatan kemampuan pemecahan masalah mahasiswa. Hasil ini sesuai dengan penelitian sebelumnya yang menyatakan bahwa pembelajaran dinyatakan sukses jika mahasiswa mencapai kompetensi dasar dalam proses pemecahan masalah seperti mampu berpikir berdasarkan konsep fisika yang relevan, mampu membuat representasi untuk membantu membuat keputusan, dan mampu menerjemahkan deskripsi fisik menjadi persamaan [33].

Penerapan pembelajaran guided inquiry berbantuan PhET belum dapat membantu secara masksimal dalam meningkatkan kemampuan pemecahan masalah mahasiswa. Hasil penelitian menunjukkan bahwa walaupun terjadi peningkatan kemampuan pemecahan masalah mahasiswa setelah dibelajarkan dengan pembelajaran guided inquiry berbantuan $\mathrm{PhET}$, akan tetapi peningkatan tersebut masih dalam kategori sedang dengan nilai $N$-Gain sebesar 0,5. Selain itu juga jika dilihat dari rata-rata nilai posttest mahasiswa sebesar 5I,03 menunjukkan masih belum tuntasnya ketercapaian mahasiswa dalam pembelajaran listrik dinamis. Beberapa kemungkinan penyebab masih belum tuntasnya ketercapaian mahasiswa adalah masih kurangnya proses latihan pemecahan masalah yang diberikan saat pembelajaran. Selain itu juga tingkat kesulitan masalah yang diberikan pada saat latihan yang belum tinggi mungkin mempengaruhi kemampuan pemecahan masalah mahasiswa.

Hal utama yang difokuskan dalam pembelajaran guided inquiry berbantuan PhET adalah bagaimana mahasiswa bisa menerapkan konsep dalam proses pemecahan masalah. Hal ini dikarenakan pengetahuan konseptual merupakan satu bagian yang harus mahasiswa ketahui untuk memecahkan masalah fisika [19]. Salah satu bagian dalam penilaian proses pemecahan masalah dari lima kriteria penilaian adalah bagaimana mengaplikasikan konsep fisika yang disebut physics approach dan aplication of physics [I5]. Selain itu juga hasil dari penelitian ini membuktikan bahwa mahasiswa yang mampu menerapkan konsep atau physics approach dan aplication of physics yang baik dalam proses pemecahan masalah cenderung menunjukkan proses pemecahan masalah yang sistematis, jelas dan memperoleh skor kemampuan pemecahan masalah yang lebih tinggi. Sedangkan mahasiswa yang hanya mengandalkan proses matematika dengan memanipulasi rumus atau memecahkan masalah secara acak dengan prosedur matematika cenderung mendapatkan skor kemampuan pemecahan masalah yang lebih rendah. Hal ini dikarenakan keberhasilan mahasiswa dalam proses matematika dalam proses pemecahan masalah tidak selalu mencerminkan mahasiswa mampu menerapkan konsep dalam proses pemecahan masalah [I2].

Kemampuan pemecahan masalah yang baik dapat membantu mahasiswa dalam mentransfer pengetahuan dan memahami situasi fisik [19], karena salah satu tujuan fisika adalah memahami situasi fisik [20]. Berdasarkan hasil penelitian diperoleh informasi bahwa ketika mahasiswa dihadapkan dengan permasalahan yang sederhana seperti tidak ada kesulitan yang dialami mahasiswa dalam memecahkan masalah, karena mereka dengan mudah menerapkan rumus dengan melihat variabel yang diketahui dalam permasalahan. Akan tetapi jika masalah yang diberikan lebih komplek dan memerlukan sebuah analisis masalah, beberapa mahasiswa mengalami kesulitan dalam proses pemecahan masalah. Temuan tersebut sesuai dengan hasil beberapa penelitian yang membuktikan bahwa walaupun mahasiswa dapat menyelesaikan masalah kualitatif dengan memasukkan nilai dalam persamaan namun mereka tidak membangun keterampilan dengan menerapkan konsep, sehingga mengalami kesulitan dalam menyelesaiakn permasalahan yang lebih kompleks [I9,2I,22]. Contoh hasil penelitian lainnya menyatakan bahwa mahasiswa tidak mengalami kesulitan menggunakan hukum Ohm untuk menyelesaikan masalah yang sederhana, akan tetapi mahasiswa banyak salah ketika menggunakan hukum Ohm untuk menganalisis rangkaian yang lebih komplek [I].

Hal menarik yang ditemukan dari penelitian ini adalah ketika mahasiswa dihadapkan pada soal-soal yang membutuhkan analisis dan tidak ada pernyataan angka, beberapa mahasiswa menggunakan anologi peminsalan matematis untuk mempermudah dalam proses pemecahan masalah. Penggunaan analogi seperti peminsalan matematis merupakan bentuk peningkatan kemampuan pemecahan masalah mahasiswa. Hal tersebut dikarenakan empat kerangka berpikir yang digunakan dalam pemecahan masalah adalah information-processing models, problem solving by analogy, resources model, and situated cognition [I6]. Hal ini menunjukkan penggunaan analogi merupakan alternatif untuk mempermudah dalam proses pemecahan masalah. 
Kemampuan Pemecahan Masalah Materi Listrik Dinamis pada Pembelajaran Guided Inquiry Berbantuan PhET pada Mahasiswa SI

\section{Kesimpulan}

Berdasarkan hasil penelitian dan pembahasan dapat disimpulkan bahwa pembelajaran guided inquiry berbantuan PhET dapat meningkatkan kemampuan pemecahan masalah mahasiswa, akan tetapi masih dalam kategori sedang. Untuk itu disarankan untuk melakukan penelitian lanjutan dengan tujuan untuk menggali lebih dalam penyebab masih belum maksimalnya peningkatan kemampuan pemecahan masalah mahasiswa setelah dibelajarkan dengan pembelajaran guided inquiry berbantuan PhET.

\section{Ucapan Terimakasih}

Ucapan terima kasih peneliti sampaikan kepada pihak Universitas Jambi, khususnya Fakultas Keguruan dan Ilmu Pendidikan program studi Pendidikan Fisika yang telah memberikan fasilitas, kesempatan dan berkontribusi dalam pengumpulan data penelitian ini.

\section{Kepustakaan}

[I] Vreeland, P, Analyzing Simple Circuit, The Physics Teacher, Vol. 40, No. 99, 2002, pp. 99-100.

[2] Stetetzer, M.R., Kampen, P.V., Shaffer, P. S \& McDermott, L. C, New Insights Into Student Understanding Of Complete Circuits And The Conservation Of Current. American Journal of Physics (Am.J.Phys), Vol. 8I, No. 2, 20I3, pp. I34-I43.

[3] Kock, Z., Taconis, R., Bolhuis, S \& Graveimejer, K, Creating A Culture Of Inquiry In The Classroom While Fostering An Understanding Of Theoretical Concepts In Direct Current Electric Circuits: A Balanced Approach, International Journal of Science and Mathematics Education (IJMSE), Vol. I3, 20I4, pp. 45-69.

[4] Ryan, Q, Computer Problem-Solving Coaches For Introductory Physics: Design And Usability Studies. Phys. Rev. ST. Phys. Educ. Res, Vol. I2, No. 0I0105, 2016

[5] Docktor, J. L., Strand, N. E., Mestre, J.P \& Ross, B. H, Conceptual Problem Solving In High School Physics. Phys. Rev. ST. Phys. Educ. Res, Vol. II, No. 020106, 2015.

[6] Vlassi dan Karaliota, The Comparison Between Guided Inquiry And Traditional Teaching Method. A Case Study For The Teaching Of The Structure Of Matter To 8th Grade Greek Students. Social and Behavioral Sciences, Vol. 93, 2013 pp. $494-497$.

[7] Bilgin, I, The Effects Of Guided Inquiry Instruction Incorporating A Cooperative Learning Approach On University Students' Achievement Of Acid And Bases Concepts And Attitude Toward Guided Inquiry Instruction. Scientific Research and Essay, Vol. 4, No. I0, 2009, pp. I038-I046.

[8] Wenning, C.J, Experimental Inquiry In Introductory Physics Course. J. Phys. Tchr. Educ, Vol. 6, No. 2, 20II, pp. 2-7.

[9] Wieman, C.E., Adam, W. K., Loeblin, P \& Perkins, K. K, Teaching Physics Sing Simulations Phet Simulations. The Physics Teacher, Vol. 8, 2010, pp. 225-227.

[10] Martinez, G., Naranjo, F. L., Perez, A. L \& Suero, M. I, Comparative Study Of The Effectiveness Of Three Learning Environments: Hyper-Realistic Virtual Simulations, Traditional Schematic Simulations And Traditional Laboratory. Phys. Rev. ST. Phys. Educ. Res., Vol 7, No. 0201 II, $201 \mathrm{I}$.
[II] Zacharia, C.Z \& Jong, D.T, One Specific Advantage For Virtual Laboratories That May Support The Acquisition Of Conceptual Knowledge Is That Reality Can Be Adapted To Serve The Learning Process. Reality Can Be Simplified By Taking Out Details. Cognition and Instruction, Vol. 32. No. 2, 20I4, pp. IOI-I58.

[12] Ceberio, M., Almudi, J.S., Franco, a, Design and Application of Interactive Simulations in Problem Solving in University-Level Physics Education. J Sci Educ Technol, DOI 10.1007/sI09560I6-9615-7, 2016

[13] Finkelstein, N.D., Adam, W. K., Keller, C. J., Kohl, P. B., Perkins, K. K.,Podolefsky, N. S., Reid, S, When Learning About The Real World Is Better Done Virtually: A Study Of Substituting Computer Simulations For Laboratory Equipment. Phys. Rev. ST. Phys. Educ. Res, Vol I, No. 0I0103, 2005.

[I4] Engelhardt,P.V dan Beichner, J.R, Students' Understanding Of Direct Current Resistive Electrical Circuits. American Journal Of Physics., Vol. 72, No. I, 2004, pp. 98-II5.

[15] Docktor, J.L., Dornfeld, J., Frodermann, E., Heller, K., Hsu, L., Jackson, K.A., Mason, A., Qing X. Ryan and Yang, J, Assessing Student Written Problem Solutions: A Problem-Solving Rubric With Application To Introductory Physics. Phys. Rev. ST. Phys. Educ. Res, Vol. I2, No. 010130, 2016.

[16] Docktor \& Mestre, Synthesis Of Discipline-Based Education Research In Physics. Phys. Rev. ST. Phys. Educ. Res, Vol. I0, No. 020II9, 2014.

[17] Urhahne,D, Role of the Teacher in Computer-supported Collaborative Inquiry Learning. International Journal of Science Education (IJSE), Vol. 32, No. 2, 2010, pp. 22I-243.

[18] Ogilvie, C.A, Changes in Students Problem Solving strategies in a Course That Includes Context -Rich, Multifaceted Problems. Phys. Rev. ST. Phys. Educ. Res, Vol 5, No. 020102, 2009.

[19] Walsh, L., Howard, R and Bowe, B, Phenomenographic Study Of Students' Problem Solving Approaches In Physics. Phys. Rev. ST. Phys. Educ. Res, Vol. 8, No. 010I23, 2007.

[20] Galili, I and Goihbarg, E, Energy transfer in electrical circuits: A qualitative account, American Journal Of Physics, Vol. 73, No. 2, 2005, pp. I4I-I 44.

[2I] Redish, E, Changing Student Ways Of Knowing: What Should Our Students Learn In A Physics Class, 2005.

[22] Rosengrant, D., Heuvelen, A and Etkina, E, Do Students Use And Understand Free-Body Diagrams?. Phys. Rev. ST. Phys. Educ. Res, Vol. 5, No, 010108, 2009.

[23] Hull, M.M ., Kuo, E., Gupta, A \& Elby, A, Problem-Solving Rubrics Revisited: Attending To The Blending Of Informal Conceptual And Formal Mathematical Reasoning, Phys. Rev. ST. Phys. Educ. Res, Vol. 9, No. 010105, 2013.

[24] Lustick, D. The failure of Inquiry: Preparing Science Teachers with an Authentic Investigation, Vol.20, 2009, pp. 583-604.

[25] Smithenry, D.W, Integrating Guided Inquiry into a Traditional Chemistry Curricular Framework. International journal of science education. Vol. 32, No. I3, 2010, pp. I689-I7I4.

[26] Bell, T., Urhahne, D., Schanze, S., Plouzhner, R, Collaborative Inquiry Learning: Models, Tools, And Challenges. International Journal of Science Education. Vol. 32, No. 3, 2010, pp. 349377.

[27] Akerson, L.V., Hanson, D. L., Cullen, T.A, The Influence of Guided Inquiry and Explicit Instruction on K-6 Teachers' Views of Nature of Science. J Sci Teacher Educ, Vol. I8, 2007, pp. 75I-772.

[28] Furtak, E.M, The Problem with Answer : An Exploration of Guided Scientific Inquiry Teaching, Vol. 90, No. 3, 2006, pp. 453-467.

[29] Lynn, H.B, Guided Inquiry Using the 5E Instructional Model with High School Physics, M.Sc, Thesis, Montana State University, Bozemen, Montana, 2012. 
Kemampuan Pemecahan Masalah Materi Listrik Dinamis pada Pembelajaran Guided Inquiry Berbantuan PhET pada Mahasiswa SI

[30] Capps, D.E \& Crawford, B, Inquiry based Instruction and Teaching About Nature of Science : Ae The Happening, J $S_{c i}$ Teacher Educ, 2012.

[3I] Perkins,K,. Adam, W., Dubson, M., Finkeilstein, N., Reid, S., Wieman, C, Lemaster, R, PhET: Interactive Simulations for Teaching and Learning Physics. The Physics Teacher. Vol. 44, 2006, pp. 18-23.

[32] Moore, E.B., Herzog, T. A \& Perkins, K. K, Interactive Simulations As Implicit Support For Guided-Inquiry. Chem. Educ. Res. Pract, Vol. I4, 20I3, pp. 257-268.

[33] Hull, M.M ., Kuo, E., Gupta, A \& Elby, A, Problem-Solving Rubrics Revisited: Attending To The Blending Of Informal Conceptual And Formal Mathematical Reasoning. Phys. Rev. ST. Phys. Educ. Res., Vol. 9, No. 010105, 2013. 